StANiseAw PRUTis ${ }^{1}$

\title{
Ochrona środowiska za pomocą instrumentów prawno-finansowych Wspólnej Polityki Rolnej
}

\section{Rolnictwo a ochrona środowiska}

Relacje pomiędzy rolnictwem jako działem gospodarki a ochroną środowiska, rozumianą jako działanie (zaniechanie) mające na celu zachowanie (przywrócenie) równowagi przyrodniczej, zawsze wykazywały specyficzny charakter. Dzieje się tak dlatego, że produkcja rolnicza, w odróżnieniu od innych dziedzin działalności gospodarczej, związana jest ze środowiskiem naturalnym, z warunkami przyrodniczymi. Istotną cechą produkcji rolnej jest związanie z ziemią, jako podstawowym, niezastępowalnym czynnym środkiem produkcji, a ściśle rzecz biorąc $-\mathrm{z}$ glebą, górną warstwą powierzchni ziemi, w której zachodzą biologiczne procesy produkcji roślinnej. Produkcja zwierzęca - hodowla i chów zwierząt, gospodarskich i domowych, to również procesy biologiczne zachodzące wśród istot żywych. Rolnictwo jest produkcyjnym wykorzystaniem naturalnego środowiska przyrodniczego zgodnie z jego przeznaczeniem; mówiąc cywilistycznie - rolnictwo jest pobieraniem pożytków naturalnych środowiska w procesie produkcji. Nie ma rolnictwa bez środowiska przyrodniczego.

Skoro rolnictwo jest gospodarczym korzystaniem z zasobów przyrody, to rolnik - siłą faktu - pełni jednocześnie funkcję producenta rolnego oraz funkcję podmiotu korzystającego ze środowiska. ${ }^{2}$ Problemem, teoretycznym i praktycznym, jest wyważenie wzajemnych relacji, czy proporcji pomiędzy tymi funkcjami. W modelowym ujęciu teoretycznym miernika dostarcza koncepcja zrównoważonego rozwoju rolnictwa, jako element szerszej kategorii - zrównoważonego rozwoju gospodarczego. Kierunkowa, konstytucyjna ${ }^{3}$ zasada zrównoważonego rozwoju ${ }^{4}$ stanowi

\footnotetext{
Uniwersytet w Białymstoku.

2 Por. M. A. Król, Producent rolny jako podmiot korzystający ze środowiska, „Studia luridica Agraria”, t. XI, s. 277291.

3 Zgodnie z art. 5 Konstytucji RP z dnia 2 kwietnia 1997 r., Rzeczpospolita Polska (...) zapewnia ochronę środowiska, kierując się zasadą zrównoważonego rozwoju.

4 Por. D. Pyć, Zrównoważony rozwój, hasło [w:] Wielka Encyklopedia Prawa - T. III - Prawo Unii Europejskiej, Z. Brodeckiego (red.), Warszawa 2014.
} 
swoisty miernik zapewnienia poziomu ochrony środowiska. Wydaje się, iż konstytucyjny zapis jest wyrazem aprobaty zasad ogólnych Deklaracji z Rio w sprawie środowiska i rozwoju, w szczególności zaś zasady 4 stanowiącej swoistą dyrektywę: „Aby osiągnąć zrównoważony rozwój, ochrona środowiska powinna stanowić nierozłączną część procesu rozwoju i nie może być rozpatrywana oddzielnie od niego". ${ }^{5} \mathrm{~W}$ polskim prawie ochrony środowiska „zrównoważony rozwój” określa się jako taki rozwój społeczno-gospodarczy, w którym następuje proces integrowania działań politycznych, gospodarczych i społecznych, z zachowaniem równowagi przyrodniczej oraz trwałości podstawowych procesów przyrodniczych, w celu zagwarantowania możliwości zaspokajania podstawowych potrzeb poszczególnych społeczności lub obywateli współczesnego pokolenia, jak i pokoleń przyszłych. ${ }^{6}$ W ujęciu teoretycznym, zrównoważony rozwój to integracja działań mających zapewnić w jakiejś dziedzinie równoważne traktowanie kilku, a przynajmniej dwu celów - gospodarczego (produkcyjnego) oraz środowiskowego.

Konstatacje powyższe odnoszą się także do rolnictwa. Zrównoważony rozwój rolnictwa to nowoczesna koncepcja programowania rozwoju wsi i rolnictwa, która kojarzy cele produkcyjne z wymaganiami środowiskowymi. Działania ekologiczne stanowią element zrównoważonego rolnictwa. Trwały rozwój zrównoważonego rolnictwa jest skierowany na harmonizowanie celów społecznych, ekonomicznych i ekologicznych, prowadzących do wzrostu jakości życia dzisiaj, z zachowaniem możliwości zaspokajania potrzeb przyszłych pokoleń. ${ }^{7}$

Akceptując stanowisko o potrzebie harmonizacji celów produkcyjnych oraz celów ekologicznych w programach Wspólnej Polityki Rolnej oraz w regulacjach prawnych wdrażających te programy podzielam jednak pogląd, iż unijne regulacje prawne, szczególnie te ustanowione na okres budżetowy 2014-2020, wyraźnie akcentują realizację funkcji ochrony środowiska, co zostało w nauce określone jako „ekologizacja” prawa rolnego. ${ }^{8}$

\section{Ekologizacja Wspólnej Polityki Rolnej w unijnych postanowieniach traktatowych}

W treści aktualnie obowiązujących traktatów stanowiących podstawę Unii Traktacie o Unii Europejskiej ${ }^{9}$ oraz Traktacie o funkcjonowaniu Unii Europejskiej ${ }^{10}$ zarówno rolnictwo (i rybołówstwo), jak i środowisko stanowią odrębne, głów-

Deklaracja z Rio o środowisku i rozwoju, Rio de Janeiro - 14 czerwca 1992.

Por. art. 3 pkt. 50 ustawy z dnia 27 kwietnia 2001 r. - Prawo ochrony środowiska (tekst jedn. Dz.U. z 2013 r., poz. 1232).

B. Jeżyńska, Zrównoważony rozwój rolnictwa, hasło [w:] Wielkaj Encyklopedia Prawa - T. VIII - Prawo rolne i żywnościowe, S. Prutis (red.), (w druku).

Por. R. Budzinowski [w:] Prawo rolne, P. Czechowski (red.), Warszawa 2013, s. 29.

Dz.Urz. UE. C 326 z dnia 26 października 2012 r., s. 13.

Dz.Urz. UE. C 326 z dnia 26 października 2012 r., s. 47. 
ne dziedziny, w których Unia wykonuje kompetencję dzieloną z państwami członkowskimi (art. 4 TfUE). Zakres i warunki wykonywania kompetencji Unii określają postanowienia Traktatów odnoszące się do każdej dziedziny. Gdy chodzi o rolnictwo i rybołówstwo jest to tytuł III (art. 38-44), natomiast środowisko to tytuł XX (art. 191-193), zamieszczone w części trzeciej TfUE zatytułowanej: Polityki i działania wewnętrzne Unii. Traktatowe regulacje zadaniowe nie zawierają postanowień dotyczących relacji pomiędzy obiema dziedzinami.

Możliwości i podstawę prawną ekologizacji WPR zapewniają postanowienia wspólne (ogólne) obu traktatów. Zgodnie z art. 3 ust. 3 TUE, Unia działa na rzecz trwałego rozwoju Europy, którego podstawą jest zrównoważony wzrost gospodarczy oraz stabilność cen, społeczna gospodarka rynkowa o wysokiej konkurencyjności zmierzająca do pełnego zatrudnienia i postępu społecznego oraz wysoki poziom ochrony i poprawy jakości środowiska. Ekologiczne podejście funkcjonalne preferują postanowienia art. 11 oraz 13 TfUE. Ogólne znaczenie odgrywa dyrektywa art. 11, że przy ustalaniu i realizacji polityk i działań Unii, w szczególności w celu wspierania zrównoważonego rozwoju, muszą być brane pod uwagę wymogi ochrony środowiska. Przepis ten dotyczy wszelkich polityk Unii, a więc i WPR. Natomiast zgodnie z art. 13 przy formułowaniu i wykonywaniu polityki rolnej, rybołówstwa i transportu oraz polityk dotyczących rynku wewnętrznego należy w pełni uwzględniać wymagania w zakresie dobrostanu zwierząt jako istot zdolnych do odczuwania, przy równoczesnym przestrzeganiu przepisów prawnych i administracyjnych oraz zwyczajów państw członkowskich związanych z obyczajami religijnymi, tradycjami kulturowymi i dziedzictwem regionalnym. Nie ma zatem żadnych zastrzeżeń co do legalności ekologizacji unijnego prawa rolnego, dyskusyjna może być wszakże zasadność i celowość oraz intensywność stawianych wymagań proekologicznych, a szczególnie proporcje pomiędzy działaniami, czy wsparciem proekologicznym a proprodukcyjnym, realizowanym w konkretnym pakiecie instrumentów polityki rolnej. Relacje pomiędzy funkcjami ekologicznymi a funkcjami produkcyjnymi, składającymi się na modelowy zintegrowany, czy zrównoważony rozwój rolnictwa przybierały w polityce rolnej, a zwłaszcza w praktyce gospodarczej rolnictwa unijnego różnorodne postaci.

Wspólna Polityka Rolna to polityka jednolitego funkcjonowania, wspierania i ochrony sektora rolnego w państwach członkowskich Unii Europejskiej. Zasady i cele WPR określone w Traktacie rzymskim z 25 marca 1957 r., ustanawiającym Europejską Wspólnotę Gospodarczą (TEWG), zostały przejęte przez uregulowania obecnie obowiązującego TfUE. I, co charakterystyczne, w ciągu ponad 50-ciu lat realizacji WPR, pomimo wielu istotnych reform tej polityki, ustawodawca unijny nie zdecydował się na zmianę zapisu regulacji prawnej w zakresie tych celów. Zgodnie z art. 39 TfUE, celami Wspólnej Polityki Rolnej są: 
a) zwiększenie wydajności rolnictwa przez wspieranie postępu technicznego, racjonalny rozwój produkcji rolnej, jak również optymalne wykorzystanie czynników produkcji;

b) zapewnienie w ten sposób odpowiedniego poziomu życia ludności wiejskiej, zwłaszcza przez podniesienie indywidualnego dochodu osób pracujących $\mathrm{w}$ rolnictwie;

c) stabilizacja rynków;

d) zagwarantowanie bezpieczeństwa dostaw;

e) zapewnienie rozsądnych cen w dostawach dla konsumentów.

Nadto, przy ustalaniu WPR i specjalnych środków służących jej realizacji uwzględnia się:

a) szczególny charakter gospodarki rolnej, wynikający ze struktury społecznej rolnictwa oraz z różnic strukturalnych i przyrodniczych między poszczególnymi regionami rolniczymi;

b) potrzebę stopniowego wprowadzania odpowiednich środków dostosowawczych;

c) fakt, że w państwach członkowskich rolnictwo jest sektorem ściśle powiązanym z całą gospodarką.

W doktrynie podkreśla się, że cele określone w art. 39 ust. 1 związane są przede wszystkim z krótkookresową polityką dochodową i rynkową, natomiast w ust. 2 art. 39 zawarto postanowienia stanowiące podstawę długookresowej polityki strukturalnej, choć oczywiście polityki te są ze sobą wzajemnie powiązane. ${ }^{11}$ Postanowienia traktatu nie wprowadzały hierarchii celów, jednakże - zdaniem moim - zwiększenie wydajności produkcji rolnej było tym celem, który warunkował możliwość zajęcia się racjonalną realizacją pozostałych celów. Wobec odmienności celów i ich potencjalnej sprzeczności kwestie te stały się przedmiotem orzecznictwa Trybunału Sprawiedliwości, który stwierdził, że cele WPR muszą być interpretowane w sposób umożliwiający instytucjom wspólnotowym wykonywanie ich obowiązków w świetle rozwoju rolnictwa i gospodarki, jako całości. Cele WPR nie muszą być realizowane jednocześnie, lecz sukcesywnie, w zależności od aktualnej sytuacji w sektorze rolnym Unii. W orzeczeniu Beus ${ }^{12}$ Trybunał dopuścił możliwość przyznawania priorytetów poszczególnym celom, w zależności od panujących warunków i konieczności realizacji w danym momencie tylko niektórych celów. Zgodnie z orzecznictwem Trybunału żaden z celów nie jest nadrzędny, a priorytet nadany jednemu z nich może mieć jedynie charakter tymczasowy, zaś ich koordynacja musi być sta- 
ła. ${ }^{13}$ Uzasadnieniem tak elastycznej konstrukcji celów WPR jest konieczność ciągłej oceny ogólnej sytuacji gospodarczej Unii, co wiąże się z kompleksowością WPR. Przyznawanie pierwszeństwa poszczególnym celom pozostawione zostało ustawodawcy unijnemu ${ }^{14}$ który dokonał licznych reform polityki rolnej bez zmian w katalogu celów polityki rolnej - w art. 39 TEWG i w art. 39 TfUE cele te są sformułowane identycznie. I co istotne, cele sformułowane w taki sposób dotyczyły produkcji rolnej, rynku rolnego, poziomu dochodowości ludności rolniczej, a więc „mieściły się" w dziedzinie rolnictwa jako działu gospodarki narodowej. Traktaty ustanawiające Europejską Wspólnotę Gospodarczą (TEWG) nie zawierały w chwili ich przyjęcia żadnych bezpośrednich odniesień do ochrony środowiska.

Polityka i prawo ochrony środowiska w Unii Europejskiej kształtowały się stopniowo $w$ miarę poszerzania i pogłębiania integracji europejskiej. Rozwój tej gałęzi prawa wiązał się ściśle z koniecznością pogodzenia postępu gospodarczego z wymogami chronienia środowiska. Traktatowe podstawy do tworzenia przez Wspólnotę polityki i prawa ochrony środowiska wprowadził Jednolity Akt Europejski z 1986 r., ${ }^{15}$ który do części III TEWG dodał tytuł VII „Środowisko naturalne" (art. 130r-130t). Akt uznał także wymagania dotyczące ochrony środowiska za niezbędny składnik innych polityk, w tym polityki rolnej. Zagadnienia ochrony środowiska rozwijały kolejne zmiany traktatowego prawa unijnego. ${ }^{16} \mathrm{Na}$ kanwie tych regulacji Trybunał Sprawiedliwości rozwinął serię tzw. wymogów interesu ogólnego, do których należą zdrowie publiczne i zdrowie zwierząt, ochrona konsumenta, ochrona środowiska naturalnego i które ustawodawca unijny powinien brać pod uwagę przy wykonywaniu swoich uprawnień, przyjmując regulacje prawne z zakresu WPR. ${ }^{17}$

W konsekwencji zmian podstaw traktatowych, ochrona środowiska w toku realizacji WPR doznawała istotnych ewolucyjnych przeobrażeń. Po 30 latach intensywnego rozwoju produkcji rolnej, służącego zwiększeniu produktywności rolnictwa i zagwarantowaniu bezpieczeństwa dostaw żywności, w którym to okresie nie dostrzegano problemu dewastacji środowiska naturalnego, nastał kryzys nadprodukcji żywności i związanych z tym wysokich kosztów magazynowania produktów rolnych. Na lata 90-te ubiegłego wieku przypadają reformy polityki rolnej mające na celu stopniowe zmiany w zasadach wspierania sektora rolnego Unii. Model „proprodukcyjny” z biegiem lat przekształcił się w model limitowania produkcji rolnej, a najważniejszymi zadaniami reformy było zrównoważenie rynków rolnych,

13 Sprawa nr 5/73 Balkan-Import-Export GmbH v. Hauptzollamt Berlin-Packhof, Zbiór Orzeczeń 1973, s.1091.

14 Por. D. Milanowska, Zadania Wspólnej Polityki Rolnej, hasło [w:] Wielka Encyklopedia Prawa - T. VIII - Prawo rolne i żywnościowe, op.cit.

15 Por. M. Michalak, Prawo ochrony środowiska Unii Europejskiej, hasło [w:] Wielka Encyklopedia Prawa - T. V Prawo ochrony środowiska, M. Górski, J.Stelmasiak (red.), Warszawa 2014.

16 Por. także zamieszczone w tomie V WEP hasło: Traktaty Unii Europejskiej.

17 Por. D. Milanowska, Zadania..., op.cit. 
poprawa konkurencyjności wspólnotowego rolnictwa, a także ekstensyfikacja metod gospodarowania $\mathrm{w}$ rolnictwie zgodnie $\mathrm{z}$ wymogami ochrony środowiska. ${ }^{18}$

Agenda 2000 to zbiorcze, hasłowe określenie programu reform WPR zaprojektowanych, wdrażanych i korygowanych na kanwie tzw. raportu Fischlera. Reforma ta zakładała dalsze urynkowienie rolnictwa, wzmocnienie jego konkurencyjności na rynkach światowych, jak również kontynuowanie rozwoju strukturalnego i ekologicznego obszarów wiejskich. Polityka Unii w sektorze rolnictwa miała zatem służyć wzmocnieniu ochrony środowiska naturalnego i rozwoju regionalnego. Reforma podkreślała znaczenie polityki rozwoju obszarów wiejskich i polityki ochrony środowiska w ramach WPR, a także zwiększenie bezpieczeństwa i jakości produktów rolnych. W konsekwencji przeglądu skuteczności Agendy 2000, na szczycie w Luksemburgu w 2003 roku Rada UE przyjęła dokument przewidujący wprowadzenie dalszych zmian w polityce rolnej na lata 2004-2013; zmiany polegały m.in. na uzależnieniu otrzymywania wsparcia przez rolnika od przestrzegania przez niego określonych standardów w zakresie ochrony środowiska naturalnego, właściwego traktowania zwierząt i bezpieczeństwa żywności. ${ }^{19}$ Szczegółowa analiza aktów programowych i aktów prawnych dokumentujących tezę ekologizacji WPR wykracza poza potrzeby niniejszych rozważań. Dlatego też ograniczę się do prezentacji powiązania instrumentów finansowo-prawnych ochrony środowiska naturalnego, z dwoma podstawowymi kierunkam działań wspierających rolnictwo unijne w XXI wieku, a mianowicie: z systemem dopłat bezpośrednich oraz z systemem wsparcia rozwoju obszarów wiejskich.

\section{Ochrona środowiska w systemie dopłat bezpośrednich oraz w systemie organizacyjno-prawnym wsparcia rozwoju obszarów wiejskich}

Począwszy od Agendy 2000 mamy obecnie do czynienia z trzecim już okresem budżetowym UE obejmującym lata 2014-2020. Czasokresy poprzednie to lata 2000-2006 oraz lata 2007-2013. W każdym z okresów obowiązywały stosowne, wzajemnie zintegrowane regulacje prawne, określające zasady i warunki dostarczenia rolnictwu środków finansowych, w formie systemu wsparcia bezpośredniego lub systemu wsparcia rozwoju obszarów wiejskich. Wśród warunków wsparcia finansowego istotne miejsce zajmowały zawsze wymagania dotyczące ochrony środowiska, formułowane jako zachęty do działań proekologicznych, podejmowania dobrowolnych zobowiązań, czy też nakładane jako obowiązki publicznoprawne. Cechą charakteryzującą zmiany jest stopniowe narastanie wymagań ekologicznych, a w konsekwencji zwiększanie zakresu obowiązków w tym obszarze.

Szerzej na ten temat por. A. Jurcewicz, Ewolucja Wspólnej Polityki Rolnej, [w:] Prawo rolne, P. Czechowski (red.), Warszawa 2013, s. 92.

Por. Prawo i polityka rolna Unii Europejskiej, op. cit. 
W pierwszym okresie trzon ówcześnie obowiązującej regulacji stanowiły 2 rozporządzenia Rady (WE) z dnia 17 maja 1999 r.:1) nr 1259/1999 - ustanawiające wspólne zasady dla systemów wsparcia bezpośredniego w ramach WPR $\left.{ }^{20} ; 2\right) \mathrm{nr}$ $1257 / 1999$ w sprawie wsparcia rozwoju obszarów wiejskich z EFOGR oraz zmieniające i uchylające niektóre rozporządzenia. ${ }^{21}$ Zgodnie z preambułą rozporządzenia nr 1259/1999, płatności bezpośrednie miały być realizowane na rzecz beneficjenta przez właściwe władze krajowe, dlatego też i problematykę ochrony środowiska powierzono państwom członkowskim. W preambule określono, że państwa te powinny przyjąć odpowiednie środki w zakresie ochrony środowiska, dotyczące użytków rolnych i produkcji rolnej, objętej płatnościami bezpośrednimi; powinny również decydować o konsekwencjach w przypadku nieprzestrzegania wymogów ochrony środowiska, w tym powinny zostać upoważnione nawet do zlikwidowania korzyści przypadających $w$ ramach systemów wsparcia, jeżeli te wymogi ochrony środowiska nie są przestrzegane. Takie środki powinny zostać podjęte przez państwa członkowskie niezależnie od możliwości udzielania pomocy w zamian za opcjonalne zobowiązania środowiskowe. Ochrona środowiska w systemie płatności bezpośrednich ujęta była fakultatywnie i bardzo elastycznie; w Polsce bezpośrednio po wejściu do UE ochrony takiej nie wprowadzono.

Gdy chodzi zaś o wsparcie rozwoju obszarów wiejskich, rozporządzenie nr 1257/1999 nawiązywało do obowiązujących wcześniej rozwiązań wskazując, że już reforma polityki z 1992 r. położyła nacisk na wymiar środowiskowy rolnictwa jako największego użytkownika ziemi. Istotna, chyba pierwsza tego typu, konstatacja dotyczyła miejsca obszarów wiejskich w polityce rolnej UE. Deklaracja programowa wskazywała, że: wspólna polityka rozwoju obszarów wiejskich powinna towarzyszyć innym instrument. wspólnej polityki rolnej oraz je uzupełniać, a zatem uczestniczyć w osiąganiu celów polityki ustanowionych w art. 33 ust. 1 (obecnie art. 39 ust. 1) Traktatu, a ramy zreformowanej polityki rozwoju obszarów wiejskich powinny objąć wszystkie obszary wiejskie Wspólnoty. ${ }^{22}$ Odnośnie ochrony środowiska na tych obszarach, rozporządzenie przewidywało wsparcie dla istniejących już (od 1992 r.) przedsięwzięć rolnośrodowiskowych, zapowiadając położenie nacisku na instrumenty rolnośrodowiskowe dla wsparcia zrównoważonego rozwoju obszarów wiejskich i w celu reakcji na rosnące społeczne zapotrzebowanie na usługi w tym zakresie. System pomocy rolnośrodowiskowej powinien być kontynuowany w celu zachęcenia rolników, by służyli społeczeństwu jako całości poprzez stosowanie praktyk gospodarki rolnej zgodnych z rosnącą potrzebą ochrony i poprawy środowiska, zasobów naturalnych, różnorodności genetycznej, gleby oraz utrzymania stanu krajobrazu i obszarów wiejskich. Szczególny wysiłek jest potrzebny dla

20 Dz.Urz. WE L 160 z dnia 26 czerwca 1999 r., str. 113.

21 Dz.Urz. WE L 160 z dnia 26 czerwca 1999 r., str. 80.

22 Por. akapit 1 oraz 9 preambuły rozporządzenia nr 1257/1999. 
kształcenia rolników i informowania ich o metodach prowadzenia gospodarki rolnej przyjaznych dla środowiska. ${ }^{23}$ Działanie systemu pomocy rolnośrodowiskowej zostało uzupełnione systemem dla obszarów o niekorzystnych warunkach gospodarowania i obszarów z ograniczeniami rolnośrodowiskowymi.

W okresie drugim (lata 2007-2013) analizowane zagadnienia ochrony środowiska w ramach wsparcia finansowego rolnictwa oraz rozwoju obszarów wiejskich regulowały: 1) rozporządzenie Rady (WE) nr 1782/2003 z dnia 29 września 2003 r. ustanawiające wspólne zasady dla systemów wsparcia bezpośredniego w ramach wspólnej polityki rolnej i ustanawiające określone systemy wsparcia dla rolników ${ }^{24}$ oraz 2) rozporządzenie Rady (WE) z dnia 20 września 2005 r. w sprawie wsparcia rozwoju obszarów wiejskich przez Europejski Fundusz Rolny na rzecz Rozwoju Obszarów Wiejskich (EFRROW) ${ }^{25}$ Pierwsze z rozporządzeń ustanowiło wspólne warunki dla płatności bezpośrednich w ramach poszczególnych systemów wsparcia dochodowego WPR. Zgodnie z akapitem 2 preambuły, płatność pełnej kwoty pomocy bezpośredniej powinna zostać powiązana ze spełnieniem zasad odnoszących się do gruntów rolnych, produkcji i działalności rolniczej. Zasady te powinny służyć włączeniu w organizację wspólnego rynku podstawowych norm z zakresu ochrony środowiska, bezpieczeństwa żywności, zdrowia i dobrostanu zwierząt oraz $\mathrm{w}$ dobrej kulturze rolnej zgodnej z ochroną środowiska. Jeżeli takie podstawowe normy nie są spełniane, państwa członkowskie powinny cofnąć pomoc bezpośrednią w oparciu o kryteria proporcjonalności, obiektywności i stopniowości. W konsekwencji regulacji rozporządzenia, rolnik ubiegający się o płatności bezpośrednie był zobowiązany do spełnienia i przestrzegania wymogów i norm składających się łącznie na mechanizm wzajemnej zgodności. Istotą wzajemnej zgodności (art. 3-9 rozporządzenia) było powiązanie wysokości uzyskiwanych płatności bezpośrednich ze spełnieniem przez rolnika wymogów podstawowych w zakresie zarządzania (ustanawianych na mocy prawodawstwa wspólnotowego w obszarach: zdrowie publiczne, zdrowie zwierząt oraz zdrowotność roślin; środowisko; dobrostan zwierząt) oraz zasad dobrej kultury rolnej zgodnej z ochroną środowiska (ustanawianych przez państwa członkowskie na podstawie norm ramowych przewidzianych w załączniku do rozporządzenia). Niezastosowanie się do wymogów podstawowych w zakresie zarządzania lub do zasad dobrej kultury rolnej zgodnej z ochroną środowiska powodowało zmniejszenie lub anulowanie kwoty przyznawanych płatności bezpośrednich. $Z$ punktu widzenia ochrony środowiska produkcji rolnej istotne ustalenia dotyczą poszczególnych kategorii użytków rolnych - wszystkie grunty rolne, a w szczególności grunty, które nie są już wykorzystywane do celów produkcyjdzenie Rady (WE) nr 73/2009 z dnia 19 stycznia 2009 r. ustanawiające wspólne zasady dla systemów wsparcia bezpośredniego dla rolników w ramach wspólnej polityki rolnej, Dz.Urz. UE L 30 z dnia 31 stycznia 2009 r., s. 16. Dz.Urz. UE L 277 z dnia 21 października 2005 r., s. 1. 
nych, miały być utrzymywane w dobrej kulturze rolnej zgodnej z ochroną środowiska. Uznając, że pastwiska trwałe mają pozytywny wpływ na środowisko, zalecane były działania zachęcające do utrzymania istniejących trwałych pastwisk, aby uniknąć ich masowego przekształcenia w grunty orne.

Zgodnie z przepisem art. 4 rozporządzenia nr 1698/2005, wsparcie rozwoju obszarów wiejskich przyczyniać się miało do osiągnięcia następujących celów:

a) poprawy konkurencyjności rolnictwa i leśnictwa poprzez wspieranie restrukturyzacji, rozwoju i innowacji;

b) poprawy środowiska naturalnego i terenów wiejskich poprzez wspieranie gospodarowania gruntami;

c) poprawy jakości życia na obszarach wiejskich oraz popierania różnicowania działalności gospodarczej.

Powyższe cele były wykonywane w ramach czterech osi; jedną z nich (oś 2) była poprawa środowiska naturalnego i terenów wiejskich. Oś rozumiana była jako spójna grupa środków, których wdrożenie prowadzi do osiągnięcia szczegółowych celów i przyczynia się do realizacji celów określonych w art. 4 rozporządzenia; natomiast „środek” to zespół operacji przyczyniających się do wykonania osi. Wśród środków służących realizacji poprawy środowiska naturalnego wyróżnić można było środki ukierunkowane na zrównoważone użytkowanie gruntów w postaci m.in. płatności dla obszarów Natura 2000, płatności rolnośrodowiskowych oraz płatności z tytułu dobrostanu zwierząt. Płatności Natura 2000 udzielane były rolnikom, rocznie na hektar użytków rolnych, w celu zrekompensowania poniesionych kosztów i utraconych dochodów wynikających z niedogodności na danych obszarach związanych z wdrażaniem dyrektyw służących obszarom 2000. Płatności rolnośrodowiskowe oraz płatności z tytułu dobrostanu zwierząt udzielane były rolnikom, którzy dobrowolnie podejmowali zobowiązania rolnośrodowiskowe oraz dotyczące dobrostanu zwierząt. Płatności obejmowały dodatkowe koszty i utracone dochody wynikające z podjętych zobowiązań. Podkreślenia wymaga, że płatności rolnośrodowiskowe oraz z tytułu dobrostanu zwierząt obejmowały jedynie te zobowiązania, które wykraczały poza odpowiednie normy obowiązkowe ustanowione w danym zakresie przepisami ww. rozporządzenia Rady (WE) nr 1782/2003 oraz inne odpowiednie wymogi obowiązkowe ustanowione na mocy ustawodawstwa krajowego i określone w programie. ${ }^{26}$

Aktualne, ustanowione na okres 2014-2020, instrumenty finansowo-prawne Wspólnej Polityki Rolnej usystematyzowane ${ }^{27}$ zostały w trzech podstawowych roz-

26 Por. art. 36-40 rozporządzenie nr 1698/2005.

27 Na ten temat por. D. Milanowska, Wybrane metody systematyzacji prawodawstwa Unii Europejskiej z uwzględnieniem aktów prawnych z zakresu prawa rolnego, „Studia luridica Agraria” 2013, t. XI, s. 11-23. 
porządzeniach Parlamentu Europejskiego i Rady (UE), przyjętych jednego dnia - 17 grudnia 2013 r. i opatrzonych numerami:

a) nr 1305/2013 w sprawie wsparcia rozwoju obszarów wiejskich przez Europejski Fundusz Rolny na rzecz Rozwoju Obszarów Wiejskich (EFRROW);

b) nr 1306/2013 w sprawie finansowania wspólnej polityki rolnej, zarządzania nią i monitorowanie jej;

c) nr 1307/2013 ustanawiające przepisy dotyczące płatności bezpośrednich na podstawie systemów wsparcia w ramach wspólnej polityki rolnej..$^{28}$

Ogólne zasady finansowania WPR zawarte w rozporządzeniu nr 1306/2013, regulują m.in. rolę funduszy $-\mathrm{EFRG}^{29} \mathrm{i}$ EFRROW w finansowaniu poszczególnych kategorii wydatków rolnych. I tak, w interesującym nas przedmiocie rozważań, wydatki na płatności bezpośrednie dla rolników dokonywane są z pierwszego z funduszy, natomiast drugi - zgodnie ze swoją nazwą - „finansuje wkład finansowy Unii przeznaczony na programy rozwoju obszarów wiejskich realizowane zgodnie z prawem unijnym dotyczącym wsparcia na rzecz rozwoju obszarów wiejskich". ${ }^{30}$ Należy podkreślić, że przepisy rozporządzenia nr 1306/2013 oraz przepisy przyjęte na jego podstawie mają zastosowanie zarówno do systemu płatności bezpośrednich dla rolników, ${ }^{31}$ jak i do systemu wsparcia rozwoju obszarów wiejskich. ${ }^{32} \mathrm{Z}$ uwagi na potrzebę spójności pomiędzy regulacjami, w rozporządzeniu nr 1306/2013 zostały zamieszczone przepisy dotyczące zasady wzajemnej zgodności. Przepisy te obejmują podstawowe wymogi w zakresie zarządzania wynikające $\mathrm{z}$ prawa unijnego oraz normy utrzymania gruntów w dobrej kulturze rolnej zgodnej z ochroną środowiska, ustanowione na poziomie krajowym i wymienione w załączniku II, a odnoszące się do następujących obszarów:

a) środowisko, zmiana klimatu oraz utrzymanie gruntów w dobrej kulturze rolnej;

b) zdrowie publiczne, zdrowie zwierząt i zdrowie roślin;

c) dobrostan zwierząt (art. 93 rozporządzenia nr 1306/2013). W załączniku II znajduje się wykaz aktów prawnych (rozporządzeń i dyrektyw) określających szczegółowe wymogi lub służących ochronie ww. obszarów. ${ }^{33}$

Obowiązek realizacji zasady wzajemnej zgodności obciąża beneficjentów otrzymujących płatności bezpośrednie na podstawie rozporządzenia nr 1307/2013,

Rozporządzenia weszły w życie w dniu 20 grudnia 2013 r. - w dniu ich opublikowania w Dzienniku Urzędowym Unii Europejskiej L 347 s. 487, 549, 608. 
a także otrzymujących roczne premie na podstawie art. 28-31, art. 33 i art. 34 rozporządzenia $\mathrm{nr}$ 1305/2013 (w ramach płatności na działania związane z ochroną środowiska). Gdy beneficjent nie przestrzega norm dotyczących wzajemnej zgodności nakłada się na niego karę administracyjną.

Obowiązujące aktualnie rozporządzenie nr 1307/2013 przewiduje dwa systemy płatności bezpośrednich: a) system płatności podstawowej oraz b) system jednolitej płatności obszarowej, stosowany w Polscy. W preambule rozporządzenia wskazano, że jednym z celów nowej WPR jest poprawa wyników w zakresie oddziaływania na środowisko, poprzez zawarty w płatnościach bezpośrednich obowiązkowy element ,zazielenienia”, który będzie wspierał w całej Unii praktyki rolnicze korzystne dla klimatu i środowiska. Praktyki te powinny polegać na prostych, ogólnych, pozaumownych i corocznych działaniach, które wykraczają poza zasadę wzajemnej zgodności i są związane $\mathrm{z}$ rolnictwem, takich jak dywersyfikacja upraw, utrzymywanie trwałych użytków zielonych (w tym tradycyjnych sadów, na których drzewa owocowe o niewielkim zagęszczeniu porastają powierzchnię użytku zielonego) oraz ustanowieniu obszarów proekologicznych. Niespełnienie obowiązków wynikających z elementu ,zazielenienia” powinno podlegać karom na podstawie rozporządzenia nr 1306/2013. Biorąc pod uwagę różnorodność systemów rolniczych i zróżnicowanie środowiskowe w krajach Unii, uzasadnione jest uznanie - oprócz trzech praktyk ustanowionych w rozporządzeniu - innych praktyk, które zapewniają równoważny lub wyższy poziom korzyści dla środowiska i klimatu. O możliwości wykorzystania praktyk równoważnych decydują państwa członkowskie. ${ }^{34}$

Cele zapisane $\mathrm{w}$ preambule przybrały charakter normatywny $\mathrm{w}$ przepisach tytułu III rozdziału 3 rozporządzenia - „Płatność z tytułu praktyk rolniczych” (art. 43-47), a także w ustawie z dnia 5 lutego 2015 r. o płatnościach w ramach systemu wsparcia bezpośredniego.$^{35} \mathrm{Na}$ wszystkich hektarach kwalifikujących się do otrzymania płatności, rolnicy uprawnieni do płatności w ramach stosowanego w danym kraju systemu płatności bezpośrednich muszą przestrzegać praktyk rolniczych korzystnych dla klimatu i środowiska lub praktyk równoważnych. Jako praktyki rolnicze zakwalifikowane zostały następujące: a) dywersyfikacja upraw; b) utrzymywanie istniejących trwałych użytków zielonych; oraz c) utrzymywanie na użytkach rolnych obszaru proekologicznego. Natomiast praktyki równoważne obejmują praktyki podobne, które skutkują równoważnym lub większym poziomem korzyści dla klimatu i środowiska w porównaniu do jednej lub kilku praktyk rolniczych. Te praktyki równoważne oraz praktyka lub praktyki, którym są one równoważne, są 
wymienione w załączniku IX do rozporządzenia nr 1307/2013. ${ }^{36} \mathrm{O}$ randze, jaką prawodawca unijny nadaje płatności z tytułu omawianych praktyk rolniczych świadczy przepis art. 47 rozporządzenia, zgodnie z którym, aby sfinansować płatność, państwa członkowskie wykorzystują 30\% rocznego pułapu krajowego, określonego w załączniku II do rozporządzenia. Szczegółowe warunki płatności z tytułu praktyk rolniczych korzystnych dla klimatu i środowiska, przybierających w Polsce nazwę „płatności za zazielenienie” (ang. greenning), mających charakter tzw. płatności powiązanych, uregulowane zostały przepisami art. 2 pkt. 7 oraz art. 8-12 ustawy z dnia 5 lutego 2015 r. o płatnościach w ramach wsparcia bezpośredniego.

W obecnie obowiązujących ramach prawnych WPR, ustanowionych na lata 2014-2020, ustawodawca unijny położył szczególny nacisk na ochronę środowiska w instrumentach drugiego filara WPR, o czym świadczy rozbudowany katalog programów rolnośrodowiskowych przewidziany w rozporządzeniu $\mathrm{nr}$ 1305/2013 w sprawie wsparcia rozwoju obszarów wiejskich. Cele takiego wsparcia określa preambuła, gdzie podkreśla się, że należy ustanowić politykę rozwoju obszarów wiejskich, która powinna towarzyszyć płatnościom bezpośrednim i działaniom rynkowym w ramach WPR oraz uzupełniać je, a tym samym przyczyniać się do osiągnięcia celów tej polityki ustanowionych w TfUE. Dla zrównoważonego rozwoju obszarów wiejskich, niezbędne jest skoncentrowanie się na ograniczonej liczbie podstawowych priorytetów wyznaczonych $\mathrm{w}$ tym zakresie. ${ }^{37}$ Szczególnie ważną konstatację zamieszczono w 5 akapicie: „Priorytety unijne w zakresie rozwoju obszarów wiejskich powinny być realizowane w ramach zrównoważonego rozwoju i wspierania przez Unię celu polegającego na ochronie i poprawie środowiska (podkr. moje - S.P.), określonego w art. 11 TfUE, państwa członkowskie powinny dostarczać informacji o wspieraniu celu dotyczącego zmiany klimatu zgodnie $\mathrm{z}$ ambitnym założeniem przeznaczenia na ten cel przynajmniej $20 \%$ unijnego budżetu, przy zastosowaniu metodologii przyjętej przez Komisję". Państwa członkowskie powinny utrzymać poziom wysiłków podjętych w okresie programowania 20072013 i powinny być zobowiązane do wydawania co najmniej 30\% calkowitego wkładu EFRROW na każdy program rozwoju obszarów wiejskich dotyczący kwestii związanych z łagodzeniem zmiany klimatu i przystosowaniem się do niej, a także kwestiami środowiskowymi. Takie wydatki powinny być dokonywane poprzez płatności rolnośrodowiskowo-klimatyczne i płatności na rzecz rolnictwa ekologicznego oraz płatności dla obszarów z ograniczeniami naturalnymi lub innymi szczególnymi ograniczeniami, poprzez płatności dla leśnictwa, płatności dla obszarów Natura 2000 oraz wsparcie inwestycji na rzecz środowiska i klimatu. ${ }^{38}$ Odnotować należy nadto istotne zobowiązanie, że państwa członkowskie powinny również

Przykładowo można stwierdzić, że praktykami równoważnymi do obszarów proekologicznych są m.in. odłogowanie ekologiczne, czy przekształcenie gruntu ornego w trwałe użytki zielone wykorzystywane ekstensywnie. 
zapewnić, aby płatności dla rolników nie prowadziły do podwójnego finansowania na mocy rozporządzenia nr 1305/2013 oraz rozporządzenia nr 1307/2013. Do działań służących ochronie środowiska należy - moim zdaniem - zaliczyć działania rolnośrodowiskowo-klimatyczne oraz rolnictwo ekologiczne; płatności dla obszarów z ograniczeniami naturalnymi lub innymi szczególnymi ograniczeniami mają charakter rekompensaty $\mathrm{z}$ tytułu dodatkowych kosztów lub utraconych dochodów, związanych z ograniczeniami dla produkcji rolnej na danym terenie.

Normatywna regulacja wsparcia działań, zaliczanych do działań z zakresu ochrony środowiska na obszarach wiejskich na terenie Polski, przybiera trójszczeblową konstrukcję. Podstawę stanowi regulacja rozporządzenia nr 1305/2013, określająca cel, definicję i zakres zachowań objętych danym działaniem. Dwa szczeble regulacji krajowej to: 1) ustawa z dnia 20 lutego 2015 r. o wspieraniu rozwoju obszarów wiejskich ze środków Europejskiego Funduszu Rolnego na rzecz Rozwoju Obszarów Wiejskich w ramach PROW na lata 2014-2020, ${ }^{39}$ regulująca zadania oraz właściwość organów i jednostek organizacyjnych, a także katalog działań uznanych za wymagające wsparcia oraz stawiane wymagania oraz procedurę przyznawania pomocy finansowej oraz 2) rozporządzenie Ministra Rolnictwa i Rozwoju Wsi w sprawie szczegółowych warunków i trybu przyznawania pomocy, odrębne dla każdego z działań objętego PROW na lata 2014-2020. ${ }^{40}$

W świetle tej trójszczeblowej regulacji, działanie rolnośrodowiskowo-klimatyczne ma na celu zachowanie oraz propagowanie niezbędnych zmian w praktykach rolnych, które stanowią pozytywny wkład w środowisko i klimat. Włączenie tego działania do programów rozwoju obszarów wiejskich jest obowiązkowe na poziomie krajowym lub regionalnym. Katalog (jedno lub większą liczbę) zobowiązań ustanawiają państwa członkowskie, na całym swoim terytorium, zgodnie ze swoimi krajowymi, regionalnymi lub lokalnymi, szczególnymi potrzebami i priorytetami. Płatności tych udziela się rolnikom i ich grupom, którzy dobrowolnie podejmą się przeprowadzenia operacji obejmujących jedno lub większą liczbę zobowiązań. Płatności mogą obejmować jedynie takie zobowiązania, które wykraczają poza odpowiednie, obowiązkowe normy ustanowione zgodnie z tytułem VI rozdział I rozporządzenia (UE) nr 1306/2013, odpowiednie kryteria i minimalne działania ustalone zgodnie z art. 4 ust. 1 lit. c) ppkt (ii) oraz (iii) rozporządzenia (UE) nr 1307/2013, oraz odpowiednie minimalne wymogi dotyczące stosowania nawozów i środków ochrony roślin, a także inne odpowiednie wymogi obowiązkowe ustanowione na mocy prawa krajowego. W ramach omawianego działania nie można udzielać wsparcia na zobowiązania objęte pokrewnym, ale odrębnym, działaniem dotyczą-

40 Pomoc finansowa $w$ ramach działania „Działanie rolnośrodowiskowo-klimatyczne” regulowana jest rozporządzeniem Ministra Rolnictwa i Rozwoju Wsi z dnia 18 marca 2015 r. (Dz.U. z 2015 r. poz. 415); natomiast pomoc w ramach działania „Rolnictwo ekologiczne” reguluje rozporządzenie Ministra Rolnictwa i Rozwoju Wsi z dnia 13 marca 2015 r. (Dz.U. z 2015 r. poz. 370). 
cym rolnictwa ekologicznego. ${ }^{41}$ Na mocy przepisów ustawy z 20 lutego 2015 r., program ROW realizowany na terytorium Rzeczypospolitej Polskiej przewiduje, w ramach działania rolnośrodowiskowo-klimatycznego, dwa poddziałania: a) płatności z tytułu zobowiązań rolnośrodowiskowo-klimatycznych, b) wsparcie dla ochrony oraz zrównoważonego użytkowania i rozwoju zasobów genetycznych w rolnictwie. Na mocy rozporządzenia wykonawczego ministra, tak szeroko ujęte zobowiązanie jest realizowane $\mathrm{w}$ pakietach, a nawet $\mathrm{w}$ wariantach - rozporządzenie przewiduje 7 pakietów i 27 wariantów. ${ }^{42}$ Płatności z tytułu podjęcia omawianych działań udzielane są w postępowaniu administracyjnym, w drodze decyzji administracyjnej, wydawanej w trybie kodeksu postępowania administracyjnego, z modyfikacjami wprowadzonymi przepisami art. 27-33 ustawy z dnia 20 lutego 2015 r.

Rolnictwo ekologiczne, jako wyodrębnione działanie w ramach wsparcia rozwoju obszarów wiejskich, jest również przedmiotem trójszczeblowej regulacji prawnej. Przepisem bazowym jest w tym przypadku art. 29 rozporządzenia (UE) nr 1305/2013, zgodnie z którym wsparcia w ramach tego działania udziela się na hektar użytków rolnych rolnikom lub grupom rolników, którzy dobrowolnie podejmują się konwersji lub utrzymania praktyk i metod rolnictwa ekologicznego określonych w rozporządzeniu (WE) nr 834/200743 i którzy są rolnikami aktywnymi zawodowo w rozumieniu art. 9 rozporządzenia nr 1307/2013. W przypadku tych płatności obowiązuje również reguła, iż wsparcia udziela się jedynie w odniesieniu do zobowiązań, które wykraczają poza odpowiednie obowiązkowe normy ustanowione zgodnie $\mathrm{z}$ właściwymi przepisami. ${ }^{44}$ Zobowiązania w ramach tego działania podejmowane są na okres od pięciu do siedmiu lat, a płatności udziela się corocznie; rekompensują one beneficjent. całość lub część dodatkowych kosztów i dochodów utraconych w wyniku podjętych zobowiązań. Ustawa o rozwoju obszarów wiejskich w ramach działania „rolnictwo ekologiczne” wyodrębnia dwa rodzaje poddziałań ustalając: a) płatności na rzecz konwersji na ekologiczne praktyki i metody w rolnictwie, oraz b) płatności na utrzymanie takich praktyk i metod w rolnictwie ${ }^{45}$ płatności te są przyznawane w trybie administracyjnym na mocy decyzji kierownika biura powiatowego Agencji Restrukturyzacji i Modernizacji Rolnictwa. Rozporządzenie wykonawcze ministra ${ }^{46}$ precyzuje, iż w Polsce płatność ekologiczną przyznaje się

Por. art. 28 ust. 1, 2, 3 oraz 8 rozporządzenia nr 1305/2013.

Przykładowo pakiet 7: Zachowanie zagrożonych zasobów genetycznych zwierząt w rolnictwie obejmuje 5 wariantów dotyczących 5 gatunków zwierząt gospodarskich.

Rozporządzenie z dnia 28 czerwca 2007 r. w sprawie produkcji ekologicznej i znakowania produktów ekologicznych (Dz.Urz. U.E. L 189 z dnia 20 lipca 2007 r., s. 1).

Przepisy te zostały określone $\mathrm{w}$ art. 29 ust. 2 rozporządzenia nr 1305/2013.

Art. 3 ust. 1 pkt. 11 wyżej cytowanej ustawy.

Rozporządzenie Ministra Rolnictwa i Rozwoju Wsi z dnia 13 marca 2015 r. w sprawie szczegółowych warunków i trybu przyznawania pomocy finansowej w ramach działania „Rolnictwo ekologiczne”, (Dz.U. z 2015 r. poz. 370). 
rolnikowi, który realizuje 5-letnie zobowiązanie, w ramach pakietu albo jego wariantu. ${ }^{47}$ Rolnik realizujący zobowiązania ekologiczne:

1) posiada plan działalności ekologicznej, sporządzony, przy udziale doradcy rolnośrodowiskowego na formularzu udostępnionym przez ARMiR;

2) nie może przekształcać występujących w gospodarstwie rolnym trwałych użytków zielonych i pastwisk trwałych;

3) zachowuje elementy krajobrazu rolniczego nieużytkowane rolniczo, tworzące ostoje przyrody, określone w planie działalności ekologicznej;

4) prowadzi rejestr działalności ekologicznej, na formularzu udostępnionym przez Agencję, zawierający wykaz:

a) działań agrotechnicznych, w tym zastosowania nawozów i użycia środków ochrony roślin,

b) wypasów zwierząt - w przypadku ich prowadzenia;

5) przestrzega innych wymogów, które są określone dla poszczególnych pakietów lub ich wariantów w załączniku nr 2 do rozporządzenia ministra z dnia 13 marca 2015 r.

Jeszcze raz należy podkreślić, iż celem wsparcia rozwoju rolnictwa ekologicznego, jako działania w ramach PROW polegającego na konwersji lub utrzymaniu praktyk ekologicznych, nie jest pozyskanie finalnego produktu ekologicznego, lecz samo prowadzenie ekologicznej produkcji rolnej w ramach zrównoważonego systemu zarządzania rolnictwem, tzn. z maksymalnym poszanowaniem reguł ochrony środowiska. Oprócz tego nurtu ustawodawstwa należy wyróżnić drugi nurt, gdzie przedmiotem regulacji są wszystkie etapy produkcji, przygotowania, dystrybucji i certyfikacji ekologicznych produktów rolnych oraz ich kontroli. ${ }^{48}$ Ten drugi nurt regulacji prawnych stanowią: powołane już rozporządzenie Rady (WE) nr 834/2007 z dnia 28 czerwca 2007 r. w sprawie produkcji ekologicznej i znakowanie produktów ekologicznych ${ }^{49}$ oraz ustawa z dnia 25 czerwca 2009 r. o rolnictwie ekologicznym. $^{50}$

\section{Ochrona środowiska - cel czy funkcja Wspólnej Polityki Rolnej?}

Przedstawiona charakterystyka instrumentów finansowo-prawnych służących ochronie naturalnego środowiska przyrodniczego, będącego aktywnym czynnikiem produkcji rolnej, pozwala na szereg konstatacji. Po pierwsze, regulacje praw-

\footnotetext{
47 Pakiety i warianty dotyczą poszczególnych rodzajów upraw rolniczych z podziałem na uprawy „w okresie konwersji” oraz „po okresie konwersji”.

48 Na ten temat por. S. Prutis, Regulacje prawne produkcji ekologicznej w rolnictwie polskim, „Studia luridica Agraria" 2013, t. XI, s. 42 i n.

49 Por. przypis 43. Nowe rozporządzenie unijne zapowiadane na okres 2013-2020 nie zostało jeszcze opracowane.

50 Tekst jedn. Dz.U. z 2015 r. poz. 497.
} 
ne, wprowadzane w kolejnych okresach budżetowych WPR, świadczą o wzroście zainteresowania ustawodawcy unijnego problemami ochrony środowiska w rolnictwie; w każdym z kolejnych okresów wzrastał zakres i intensywność ochrony. Po wtóre, ewolucja ochrony środowiska prowadziła od stawiania wymagań sformułowanych ogólnikowo do ukształtowania instrumentów specjalnie skonstruowanych w celu ochrony środowiska (płatności za zazielenienie, płatności do rolnictwa ekologicznego). Po trzecie, o randze ochrony środowiska świadczy także wzrost środków finansowych przewidywanych na cele ekologiczne; dowodem tego jest zobowiązanie państw do wydawania co najmniej 30\% całkowitego wkładu EFRROW na każdy program rozwoju obszarów wiejskich, dotyczący kwestii związanych z łagodzeniem zmiany klimatu, a także kwestii środowiskowych. Po czwarte, wydaje się, że można mówić o kilku poziomach ochrony danego elementu środowiska, w zależności od zakresu wymagań stawianych rolnikowi władającemu gruntami oraz od stopnia wspomagania beneficjenta w realizacji tych wymagań. Poziom najniższy to wymogi podstawowe, wynikające z zasady wzajemnej zgodności, ustanowione na poziomie krajowym, dotyczące wszystkich beneficjentów otrzymujących płatności bezpośrednie na podstawie rozporządzenia (UE) nr 1307/2013 oraz premie na podstawie art. 28-31, art. 33 i 34 rozporządzenia (UE) nr 1305/2013..$^{51}$ Kolejny poziom ochrony wyznacza, ustanowiony w art. 43 rozporządzenia (UE) nr 1307/2013, wymóg przestrzegania praktyk rolniczych korzystnych dla klimatu i środowiska $^{52}$ - za ich realizację (w Polsce) przysługuje płatność za zazielenienie, mająca charakter tzw. płatności powiązanej w ramach płatności obszarowych. Wyższy, jak się wydaje, poziom ochrony środowiska zapewniają dobrowolne zobowiązania co do konwersji lub utrzymania metod i praktyk rolnictwa ekologicznego lub zobowiązania rolnośrodowiskowo-klimatyczne, składane przez beneficjentów w celu uzyskania płatności za tego typu działania, w ramach wsparcia rozwoju obszarów wiejskich. Mowa tu o wyższym poziomie ochrony środowiska, albowiem płatności obejmują jedynie te zobowiązania rolników, które wykraczają poza, czy ponad ustanowione obowiązkowe normy środowiskowe. Prezentowane konstatacje prowadzą do oczywistej konkluzji - ochrona środowiska stanowi integralny element (składnik) działań i instrumentów finansowo-prawnych podejmowanych w toku realizacji obu filarów WPR: polityki rynkowo-dochodowej oraz polityki rozwoju obszarów wiejskich. Czy można zatem powiedzieć, iż ochrona naturalnego środowiska rolniczego jest celem WPR?

Pamiętając o tym, że sformułowanie katalogu celów WPR pozostaje niezmienne począwszy od pierwotnego zapisu w art. 39 TEWG, nie można zająć stanowi-

51 Jeżeli beneficjent nie przestrzega przepisów dotyczących zasady wzajemnej zgodności, nakłada się na niego karę administracyjną według reguł ustanowionych przepisem art. 91 rozporządzenia (UE) nr 1306/2013. 61 ust. 3 rozporządzenia z praktyk rolniczych zwolnieni są rolnicy uczestniczący w systemie dla małych gospodarstw. 
ska, iż katalog został rozbudowany poprzez dodanie celu, jakim jest ochrona środowiska. W drodze interpretacji uwspółcześniającej ówczesne sformułowanie celów, można natomiast bronić stanowiska, że określony wówczas cel „racjonalny rozwój produkcji rolnej”, na obecnym poziomie rozwoju gospodarki żywnościowej jest tożsamy lub równoważny ze „,zrównoważonym rozwojem rolnictwa”, który jest skierowany na harmonizowanie celów społecznych, ekonomicznych i ekologicznych. Powszechnie uważa się, że obecnie „racjonalny rozwój” to „zrównoważony rozwój”, gdzie działania proekologiczne stanowią element zrównoważonego rolnictwa, a tym samym przedmiot zainteresowania polityki rolnej. Moim zdaniem, rangę i rolę ochrony środowiska we współczesnej polityce rolnej Unii Europejskiej zapewnia wyrażony w art. 11 TfUE obowiązek (,muszą być brane pod uwagę”) uwzględnienia wymogów ochrony środowiska, przy ustalaniu i realizacji polityk i działań Unii, w szczególności w celu wspierania zrównoważonego rozwoju. Klauzula wyrażona w tym przepisie nazywana jest zasadą integracji wymagań środowiskowych przy ustalaniu i realizacji innych polityk i działań $\mathbf{U E} .{ }^{53} \mathrm{~W}$ odesłaniu do tej zasady pojawiają się w najnowszych aktach prawnych UE nawiązania do celów ekologicznych. Wskazywałem już na sformułowania zawarte w preambule do rozporządzenia (UE) nr 1305/2013, że polityka rozwoju obszarów wiejskich powinna być realizowana $w$ ramach zrównoważonego rozwoju i wspierania przez Unię celu polegającego na ochronie i poprawie środowiska, określonego $\mathrm{w}$ art. $11 \mathrm{TfUE}^{54} \mathrm{~W}$ preambule do rozporządzenia (UE) nr 1307/2013 mówi się, że jednym z celów nowej WPR jest poprawa wyników w zakresie oddziaływania na środowisko poprzez obowiązkowy element ,zazielenienia” zawarty w płatnościach bezpośrednich, który będzie wspierał w całej Unii praktyki rolnicze korzystne dla klimatu i środowiska. ${ }^{55} \mathrm{~W}$ świetle powyższych dywagacji można dyskutować, czy ochrona środowiska jest ustanowionym celem WPR; nie ma natomiast wątpliwości, że ochrona taka jest celem realizowanym $w$ programach i regulacjach prawnych WPR, a mechanizmy prawne ochrony środowiska pełnią funkcję instrumentów Wspólnej Polityki Rolnej.

Konsekwencją zasady integracji wymagań środowiskowych przy ustalaniu i realizacji WPR jest właśnie „ekologizacja” prawa rolnego. Jak stwierdza R. Budzinowski, funkcja ,środowiskowa” prawa rolnego rysuje się bardzo wyraźnie, skoro wymogi środowiskowe - w ramach wielofunkcyjnego rolnictwa - zostały włączone do zadań tego sektora gospodarki; współkształtują one warunki wykonywania działalności rolniczej i stanowią jeden z parametrów jej oceny. „Środowiskowe” regulacje w ramach prawa rolnego nie stanowią jednak jakiejś odrębnej dziedziny; można je określić jako prawo-rolnośrodowiskowe, co nie odrywa go ani od prawa rolnego,

53 M. Michalak, Prawo ochrony środowiska Unii Europejskiej, hasło [w:] Wielka Encyklopedia Prawa - T. V - Prawo ochrony środowiska, op. cit.

54 Por. akapity 2 i 5 preambuły.

55 Por. akapit 37. 
ani od prawa ochrony środowiska. ${ }^{56}$ Regulacje środowiskowe muszą być przedmiotem zainteresowania doktryny prawa rolnego przynajmniej w takim zakresie, jaki jest niezbędny dla wyjaśnienia działania i oceny instytucji prawnych wdrażających WPR. Zrozumiałe jest przy tym inne położenie akcentów przez specjalistę z zakresu ochrony środowiska oraz przez specjalistę agrarystę. Rolnictwo ekologiczne może być dobrym przykładem odmiennego rozłożenia akcentów. Prawnik - ekolog określa rolnictwo ekologiczne jako, ,istotny instrument ochrony użytkowej żywych zasobów przyrody w działalności rolniczej"; ${ }^{57}$ natomiast prawnik - agrarysta stwierdza, że to sposób produkcji wytwórczej uregulowany w ustawie z dnia 25 czerwca 2009 r. o rolnictwie ekologicznym; ustawa dookreśla zadania oraz właściwość organów administracji publicznej i jednostek organizacyjnych w zakresie produkcji ekologicznej i znakowania produktów ekologicznych. ${ }^{58}$ A zatem instytucje ochrony środowiska w ramach WPR nie powinny być przedmiotem kompetencyjnych sporów doktrynalnych pomiędzy prawem ochrony środowiska a prawem rolnym.

\section{Obowiązek przestrzegania (wykonania) praktyk rolniczych korzystnych dla klimatu i środowiska}

W tytule akapitu świadomie rozgraniczono sytuacje, kiedy to ochrona środowiska w instrumentach prawnych WPR przybiera konstrukcję ustawowych wymogów (norm, standardów określonych zachowań - działań lub zaniechań), nakładając obowiązek ich przestrzegania na ogół beneficjentów, ${ }^{59}$ bez potrzeby konkretyzacji zakresu obowiązków w drodze aktu indywidualnego (decyzji administracyjnej) oraz sytuacje, kiedy ochrona polega na podjęciu zobowiązań co do zachowań ochronnych przez poszczególnych beneficjentów, których zakres określany jest w drodze wynegocjowanej decyzji administracyjnej, a obowiązek wykonania podjętych zobowiązań podlega kontroli. W takim ujęciu można uznać, że wymogów się przestrzega, a przyjęte obowiązki wykonuje.

Obowiązek przestrzegania ochrony środowiska obejmuje podstawowe wymogi ujęte w ramach zasady wzajemnej zgodności i dotyczy beneficjentów otrzymujących płatności bezpośrednie na podstawie rozporządzenia (UE) nr 1307/2013 oraz roczne premie na podstawie art. 28-31 rozporządzenia (UE) nr 1305/2013. Państwa członkowskie przekazują odnośnym beneficjent. wykaz wymogów i norm, które mają być stosowane na poziomie gospodarstwa, a także jasne i dokładne informacje na ten temat. Państwa mogą korzystać z istniejących systemów zarządzania i kontroli w celu zapewnienia zgodności z przepisami dotyczącymi zasady wzajem-

R. Budzinowski, [w:] Prawo rolne, P. Czechowski (red.), op. cit., s. 29.

M.A. Król, Rolnictwo ekologiczne, hasło [w:] Wielka Encyklopedia Prawa - T. V - Prawo ochrony środowiska, op. cit., s. 29.

A. Niewiadomski: Rolnictwo ekologiczne, hasło [w:] Wielkiej Encyklopedii Prawa - T. VIII - Prawo rolne i żywnościowe, j.w.

Przez beneficjenta rozumiem podmiot korzystający z pomocy finansowej. 
nej zgodności; przeprowadzają kontrole na miejscu w celu zweryfikowania, czy beneficjent wywiązuje się z nałożonych obowiązków. Za nieprzestrzeganie przepisów dotyczących wzajemnej zgodności na beneficjenta nakłada się karę administracyjną; karę nakłada się w jakimkolwiek momencie w ciągu danego roku kalendarzowego, oraz w przypadku, gdy taką niezgodność można bezpośrednio przypisać beneficjentowi, który złożył w danym roku kalendarzowym wniosek o przyznanie pomocy lub wniosek o płatność. ${ }^{0}$ Obliczanie i stosowanie kar administracyjnych jest dość skomplikowane, stąd wskazać trzeba na rozwiązania podstawowe. Karę administracyjną stosuje się w drodze zmniejszenia całkowitej kwoty płatności lub wykluczenia z płatności wymienionych w art. $92 \mathrm{ww}$. rozporządzenia, które zostały lub mają zostać przyznane danemu beneficjentowi w odniesieniu do wniosków o przyznanie pomocy, które złożył lub złoży w roku kalendarzowym, w którym stwierdzono nieprawidłowość. ${ }^{61}$

W przypadku płatności za zazielenienie, mających charakter płatności powiązanych, w ramach płatności obszarowych, przestrzeganie zasady wzajemnej zgodności jest konieczne, lecz nie jest wystarczające. Płatność za zazielenienie jest to płatność z tytułu praktyk rolniczych korzystnych dla klimatu i środowiska, ${ }^{62}$ polegających na: a) dywersyfikacji upraw; b) utrzymywaniu trwałych użytków zielonych; oraz c) utrzymywanie na użytkach rolnych obszaru proekologicznego. A zatem państwa członkowskie przyznają płatność za zazielenienie rolnikom, którzy przestrzegają praktyk $\mathrm{z}$ ww. katalogu, które mają w ich przypadku zastosowanie oraz w zakresie, w jakim rolnicy przestrzegają art. 44, 45 i 46 rozporządzenia, określających szczegółowo wymagania stawiane przy każdej z trzech rodzajów praktyk. Ponieważ płatność za zazielenienie wchodzi w zakres płatności bezpośrednich, o których mowa w art. 92 rozporządzenia nr 1306/2013, do kontroli przestrzegania wymaganych praktyk rolniczych i do stosowanych sankcji, w postaci zmniejszenia całkowitej kwoty płatności lub wykluczenia z płatności, stosuje się również podobne reguły, zmodyfikowane wszakże przepisami art. 9-12 ustawy z 5 lutego 2015 r. o płatnościach w ramach wsparcia bezpośredniego. I tak, rolnik, który wbrew obowiązkowi utrzymywania trwałych użytków zielonych przekształcił lub zaorał te użytki, jest obowiązany do ponownego przekształcenia tego obszaru w trwały użytek zielony, nie później niż do dnia 31 maja roku następującego po roku złożenia wniosku o przyznanie płatności bezpośrednich. Obowiązek ponownego przekształcenia stwierdza, w drodze decyzji, kierownik biura powiatowego Agencji Restrukturyzacji i Modernizacji Rolnictwa. W przypadku niewykonania obowiązku nałożonego decyzją, stosuje się odpowiednio przepisy o postępowaniu egzekucyjnym w admini-

60 Por. przepisy art. 91-97 rozporządzenia (UE) nr 1306/2013.

61 Art. 99 rozporządzenia (UE) nr 1306/2013.

62 Tak brzmi intytulacja rozdziału 3 w tytule III rozporządzenia nr 1307/2013 - art. 43-47. 
stracji dotyczące grzywny w celu przymuszenia, z tym że wierzycielem w rozumieniu tych przepisów jest kierownik biura powiatowego Agencji. ${ }^{63}$

Realizacja wymogów w zakresie ochrony środowiska zabezpieczona jest nie tylko za pomocą sankcji finansowych (kara administracyjna), ale poprzez realne wykonanie decyzji administracyjnej nakładającej obowiązek przywrócenia stanu poprzedniego w zakresie utrzymywania trwałych użytków zielonych, służących ochronie środowiska.

Mechanizmy ochrony środowiska stosowane w ramach rozwoju obszarów wiejskich najbardziej elastycznie, a jednocześnie precyzyjnie mogą określać zakres obowiązków w postaci różnorodnych działań służących takiej ochronie. Wielokrotnie już podkreślano, że rolnicy - beneficjenci korzystający ze wsparcia rozwoju obszarów wiejskich mają oczywiście obowiązek przestrzegania wymagań ujętych w ramach zasady wzajemnej zgodności. Pomoc udzielana w ramach PROW przyznawana jest za realizację zobowiązań podejmowanych dobrowolnie przez rolników, a dotyczących działań wykraczających poza odpowiednie normy i standardy obowiązkowe. Określenie katalogu działań uzyskujących wsparcie i ich ramową regulację zawierają przepisy rozporządzenia (UE) nr 1305/2013, natomiast szczegółowy tryb określania i egzekwowania zakresu obowiązków ochrony środowiska, w ramach poszczególnych działań, ${ }^{64}$ pozostawiono prawodawstwu państw członkowskich. Rozwiązanie takie dotyczy również omawianych tutaj działań: „Rolnictwo ekologiczne” ${ }^{65}$ oraz „Działanie rolnośrodowiskowo-klimatyczne”. Krajowa regulacja obowiązków ochrony środowiska, wykonywanych w ramach tych działań, przedstawiona została w akapicie 3 niniejszych rozważań. Jeszcze raz podkreślić należy szeroki zakres możliwych zobowiązań środowiskowych, realizowanych w różnorodnych pakietach lub nawet ich wariantach, wybranych przez zainteresowanych rolników, a zatwierdzonych do realizacji decyzją kierownika biura powiatowego Agencji. Sankcje z tytułu niewykonania obowiązków lub ich nienależytego wykonania mają charakter finansowy, a stosowane są w trybie administracyjnym. Sankcjami takimi są: a) zmniejszenie wysokości płatności ekologicznej, jeżeli zostanie stwierdzone uchybienie w przestrzeganiu przez rolnika wymogów w ramach poszczególnych pakietów lub wariantów; b) zwrot płatności ekologicznej, jeżeli rolnik nie realizuje całego zobowiązania ekologicznego lub nie spełnia innych warunków przyznania płatności ekologicznej określonych w rozporządzeniu. ${ }^{66}$ Płatność ekologiczna podlega zwrotowi w trybie i na zasadach określonych w przepi-

Art. 11 ustawy z dnia 5 lutego 2015 r.

Działanie - w rozumieniu przepisów rozporządzenia - oznacza zespół operacji przyczyniających się do wykonania co najmniej jednego z priorytetów unijnych w zakresie rozwoju obszarów wiejskich.

Jeśli chodzi o to działanie, to w art. 29 ust. 1 rozporządzenia zamieszczono jeszcze wymóg, aby rolnicy podejmowali się praktyk i metod rolnictwa ekologicznego, określonych w rozporządzeniu (WE) nr 834/2007 w sprawie produkcji ekologicznej i znakowania produktów ekologicznych.

Por. § 30 oraz § 31 rozporządzenia Ministra Rolnictwa i Rozwoju Wsi z dnia 13 marca 2015 r. (Dz.U. z 2015 r. poz. 370). 
sach o Agencji Restrukturyzacji i Modernizacji Rolnictwa ${ }^{67}$ (§ 31 ust. 4 rozporządzenia).

\section{Zakończenie}

Podsumowując rozważania na temat wykonania obowiązków ochrony środowiska przy wykorzystaniu instrumentów prawnych polityki rolnej stwierdzić należy, iż prawodawstwo unijne oraz krajowe wprowadza mechanizmy prawne dające należytą gwarancją elastycznej, ale i skutecznej ochrony różnorodnych elementów środowiska przyrodniczego.

Osobnym problemem jest kwestia zasadności nałożenia takiego obowiązku, którego zakres nie jest zależny, od woli podmiotu zobowiązanego; dylemat ten nie dotyczy zobowiązań podejmowanych dobrowolnie. Nałożenie obowiązku ochrony środowiska uzasadnia się potrzebą zrównoważonego rozwoju rolnictwa; zrównoważone rolnictwo jest nowoczesną koncepcją programowania wsi i rolnictwa, która kojarzy cele produkcyjne z wymaganiami środowiskowymi. I co ważne, sednem koncepcji trwałego i zrównoważonego rozwoju jest rozwój, który zaspokaja potrzeby obecnego pokolenia, nie ograniczając możliwości zaspokajania potrzeb przyszłych pokoleń. Zrównoważony rozwój jest koncepcją, która zyskała bodajże powszechną akceptację; wykracza ona znacznie poza rolnictwo jako ekosystem. Mówi się o zrównoważonym wykorzystaniu każdego ekosystemu. Szerokie spojrzenie na ekologię integralną, obejmującą ekologię środowiskową, gospodarczą i społeczną prezentuje Ojciec Święty Franciszek w Encyklice Laudato si' (W trosce o wspólny dom), gdzie wyróżnia także kategorię ,ekologia ludzka”. Ekologia ta oznacza niezbędną relację życia człowieka z prawem moralnym, wpisanym w jego naturę; relację konieczną, by można było stworzyć bardziej godne środowisko. Ludzka ekologia jest nierozerwalnie związana z pojęciem dobra wspólnego, a pojęcie to - zdaniem Papieża - dotyczy również przyszłych pokoleń. Nie można mówić o zrównoważonym rozwoju bez solidarności między pokoleniami. , Jeśli ziemia jest nam dana, to nie możemy myśleć jedynie wychodząc z utylitarnego kryterium efektywności i produktywności dla zysku indywidualnego. Nie mówimy tu o postawie opcjonalnej, ale o zasadniczej kwestii sprawiedliwości (podkr. moje - S.P.), ponieważ ziemia, którą otrzymaliśmy, należy również do tych, którzy przyjdą po nas". ${ }^{68}$ Papież powołuje w tym miejscu portugalskich biskupów, którzy w liście pasterskim z 15 listopada 2003 r. wezwali do podjęcia tego obowiązku sprawiedliwości: „Środowisko mieści się w logice przyjęcia. Jest to pożyczka, którą każde pokolenie otrzymuje i powinno przekazywać następnym pokoleniom". W świetle powyższych konstatacji, nie można mieć zastrzeżeń co do moralnego prawa inte- 
gralnego powiązania, czy kojarzenia celów produkcyjnych z wymaganiami ochrony środowiska.

Powiązanie ochrony środowiska, czyli realizacji celu publicznego, z działalnością gospodarczą w prywatnym gospodarstwie rolnym nie budzi większych zastrzeżeń z punktu widzenia zasad sprawiedliwości dystrybutywnej. Sprawiedliwość dystrybutywna odnosi się do sposobu, w jaki dokonuje się pomiędzy ludźmi rozdział „korzyści i ciężarów wynikających ze społecznej współpracy”. ${ }^{69}$ Rolnicy ponoszą niewątpliwie koszty z tytułu przestrzegania wymogów ochrony środowiska, czy też koszty podejmowania aktywnych działań stanowiących pozytywny wkład w środowisko; za poniesione na ten cel koszty rolnicy otrzymują różnego rodzaju płatności, mające stanowić rekompensatę za całość lub część dodatkowych kosztów lub dochodów utraconych, w wyniku wykonania obowiązków podjętych dobrowolnie lub określonych w ustawie. Nie sposób wykazać dokładnie, jak się mają płatności do poniesionych kosztów. Z pewnych danych ogólnych można wysnuć wniosek, że zasady sprawiedliwości są zachowane. Podstawę do takiej konstatacji mogą stanowić relacje pomiędzy płatnościami (dopłatami) a dochodami rolników. W pierwszym roku akcesji wszelkiego rodzaju dopłaty unijne stanowiły $13 \%$ dochodów rolników. W latach 2005-2008 wskaźnik ten podskoczył do 52\%, a w 2009 r. przekroczył $80 \% .^{70}$ Biorąc pod uwagę okoliczność, iż w ramach globalnej wielkości udzielanych płatności (zarówno bezpośrednich, jak i służących rozwojowi obszarów wiejskich), około $30 \%$ stanowić powinny płatności z tytułu przestrzegania wymogów ochrony środowiska, czy praktyk proekologicznych, można przeprowadzić rozumowanie, że szeroko ujęta działalność proekologiczna jest źródłem blisko $24 \%$, czyli jednej czwartej globalnych dochodów rolników. Takie proporcje pozwalają mówić o zachowaniu zasad sprawiedliwości. Dodać należy, iż rolnicy uważający system płatności za niesprawiedliwy nie mają obowiązku korzystania z syste$\mathrm{mu}$; bez wniosku rolnika system płatności nie może, w stosunku do niego, zadziałać.

Ostatni problem wymagający rozważenia to kwestia konstrukcji prawnej obowiązku, nakładanego w drodze regulacji prawnej, na ogół podmiotów będących rolnikami. Konstrukcją prawną umożliwiającą takie rozwiązanie jest doktrynalna koncepcja własności rolniczej, jaką na gruncie polskiej doktryny prawa rolnego zaproponował profesor Andrzej Stelmachowski. Według tej koncepcji własność rolnicza (wyodrębniona ze względu na przedmiot własności) jest kompleksem praw i obowiązków określających sytuację prawną podmiotu - właściciela gospodarstwa. Zdaniem Autora koncepcji, swoisty charakter gospodarstwa rolnego jako czynnej, zorganizowanej masy majątkowej powoduje, że rozwiązania cywilistyczne, które odnoszą się do rzeczy, nie wystarczają do określenia sytuacji prawnej 
zorganizowanej całości, jaką stanowi gospodarstwo rolne. I tu przydatna jest koncepcja własności rolniczej, która odnosi się do gospodarstwa rolnego jako swoistego mienia. Tak rozumiana własność rolnicza uzyskuje swój pełny obraz dopiero wtedy, gdy weźmiemy pod uwagę nie tylko przepisy Kodeksu cywilnego, ale i konglomerat przepisów różnej rangi kształtujących treść tej własności i sposób jej wykonywania. Co więcej, elementy pozacywilistyczne mają tu szczególne znaczenie; właśnie przepisy prawa publicznego regulujące zasady ochrony gruntów rolnych, czy obowiązki w zakresie ochrony środowiska wpływają w sposób pośredni na możność korzystania przez rolnika z jego własności Suma tych regulacji określa sytuację prawną rolnika. W konkluzji rozważań A. Stelmachowski stwierdza: , Cechą charakterystyczną własności rolniczej jest, że wspomniane obowiązki odnoszą się nie tylko do określonych jednostek, ile wobec państwa reprezentującego interes społeczeństwa jako całości. W zamian za należyte wykonanie własności rolniczej właściciel ma prawo liczyć na pomoc (ze strony państwa) przy wykonywaniu swego prawa własności”. ${ }^{71}$ Obecnie widać doskonale, jak koncepcja własności rolniczej, jako kompleksu praw i obowiązków rolnika, jest przydatna do wyjaśnienia nakładania na rolników publicznoprawnych obowiązków z zakresu ochrony środowiska. we, T. Dybowski (red.), Warszawa 2007, s. 189-223. 
ENVIRONMENTAL PROTECTION BY MEANS OF FINANCIAL AND LEGAL INSTRUMENTS OF THE COMMON AGRICULTURAL POLICY

Keywords: environmental protection, Common Agricultural Policy, level of environmental protection, cross-compliance principle, greening payments, direct payments, support for rural development, agricultural property

Environmental protection is an integral part (component) of actions as well as financial and legal instruments undertaken in the course of the two pillars of the Common Agricultural Policy: market and income policy and rural development policy. Such protection is the aim pursued in the programs and legal regulations of the Common Agricultural Policy, and legal mechanisms of environmental protection, act as instruments of the Common Agricultural Policy, giving reasonable assurance, flexible but effective protection of the various elements of the natural environment. Imposing an obligation to protect the environment is justified in the concept of sustainable development of agriculture, as such development meets the needs of future generations. Connection between the obligation to protect the environment, which is the public aim, with economic activity in the private farmstead, does not raise doubts from the point of view of the principles of distributive justice. The legal construction that explains such a solution is, proposed by A. Stelmachowski, the concept of agricultural property, as a complex of rights and obligations determining the legal situation of the entity - the owner of the farm. A characteristic feature of agricultural property is that these obligations relate not only to specific individuals, but to the State representing the public interest of society as a whole. In exchange for the due performance of agricultural property, the owner has the right to expect assistance from the state, when they exercise their ownership rights.

\section{Bibliografia:}

R. Budzinowski, Pojęcie i przedmiot prawa rolnego, [w:] P. Czechowski (red.), Prawo rolne, Warszawa 2013.

B. Jeżyńska, Zrównoważony rozwój gospodarczy, hasło [w:] Wielka Encyklopedia Prawa - T. VIII Prawo rolne i żywnościowe, S. Prutis (red.), (w druku).

A. Jurcewicz, Ewolucja Wspólnej Polityki Rolnej, [w:] P. Czechowski (red.), Prawo rolne, Warszawa 2013.

M.A. Król, Producent rolny jako podmiot korzystający ze środowiska, „Studia Iuridica Agraria” 2013, t. XI.

M.A. Król, Rolnictwo ekologiczne, hasło [w:] Wielka Encyklopedia Prawa - T. V - Prawo ochrony środowiska, M. Górski i J. Stelmasiak (red.), Warszawa 2014. 
M. Michalak, Prawo ochrony środowiska w Unii Europejskiej, hasło [w:] Wielka Encyklopedia Prawa - T. V - Prawo ochrony środowiska; M. Górski i J. Stelmasiak (red.), Warszawa 2014.

D. Milanowska, Wybrane metody systematyzacji prawodawstwa Unii Europejskiej z uwzględnieniem aktów prawnych z zakresu prawa rolnego, „Studia Iuridica Agraria” 2013, t. XI.

D. Milanowska, Zadania Wspólnej Polityki Rolnej, hasło [w:] Wielka Encyklopedia Prawa - T. VIII Prawo rolne i żywnościowe, S. Prutisa (red.), (w druku).

A. Niewiadomski, Rolnictwo ekologiczne, hasło [w:] Wielka Encyklopedia Prawa - T. VIII - Prawo rolne i żywnościowe; S. Prutisa (red.), (w druku).

Ojciec Święty Franciszek: Encyklika Laudato si' (W trosce o wspólny dom); polski tekst, Kraków 2015.

Prawo i polityka rolna Unii Europejskiej, A. Jurcewicz (red.), Warszawa 2010.

S.Prutis, Regulacje prawne produkcji ekologicznej w rolnictwie polskim, „Studia Iuridica Agraria” 2013, t. XI.

D. Pyć, Zrównoważony rozwój, hasło [w:] Wielka Encyklopedia Prawa - T. III - Prawo Unii Europejskiej; Z. Brodecki (red.), Warszawa 2014.

J. Rawls, Teoria sprawiedliwości, Warszawa 1994.

J. Solska, Chłopi na dopalaczach, „Polityka” nr 41 (3030)/2015 r.

A. Stelmachowski, Treść i wykonywanie prawa własności, [w:] System Prawa Prywatnego, T. 3: Prawo rzeczowe, T Dybowski (red.), Warszawa 2007. 